\title{
Geological steering of horizontal wells in chalk reservoirs - Examples from the Danish North Sea
}

\author{
MORTEN W. JEPPESEN
}

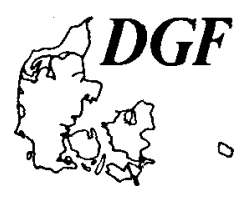

\begin{abstract}
Jeppesen, M. W.: Geological steering of horizontal wells in chalk reservoirs-Examples from the Danish North Sea. Bulletin of the Geological Society of Denmark, vol. 41, pp. 138-144. Copenhagen 1994-11-30. https://doi.org/10.37570/bgsd-1995-41-13

The reservoir position of horizontal wells drilled in low permeability chalk reservoirs is of vital importance for the well performance. Accurate placement of horizontal wells drilled in the low permeability chalk fields in the Danish North Sea is being achieved by rigorous evaluation of geological information acquired during drilling. The tools which are being utilized for geological steering of horizontal wells comprise: High resolution biostratigraphy, Logging While Drilling, shows evaluation and analysis of 3D seismic data. Examples from the Dan, Kraka, Skjold and Tyra fields illustrate the current applications of geological steering in chalk reservoirs.
\end{abstract}

M. W. Jeppesen, Marsk Olie og Gas AS, 50 Esplanaden, DK-1263 Copenhagen K, Denmark. December 2nd, 1993.

\section{Introduction}

As operating company for the Dansk Undergrunds Consortium (DUC), Mærsk Olie og Gas AS has currently (1 October 1993) drilled and completed more than 50 horizontal wells in the Danish North Sea oil and gas fields. Since the introduction of horizontal drilling in the Dan field in 1987, horizontal wells have become an integral part of the development of the six Danish chalk fields: Dan, Kraka, Gorm, Skjold, Tyra and Valdemar (Fig. 1).

The past seven years have demonstrated that horizontal wells can be very advantageous for addressing problems related to the development of low permeability chalk reservoirs (Andersen et al. 1990; Fine et al. 1992). Examples of the current objectives of horizontal wells include:

1) Development of very thin oil rims with long reach horizontal wells selectively completed to minimize water and gas production.

2) Development of fractured reservoirs by intersection of natural fracture systems.

3) Development of thick and multiple layered reservoirs by completing horizontal wells with large diameter sand-propped hydraulic fractures.

4) Water flooding.

5) Appraisal of flank areas.

From a geological viewpoint the success of horizontal drilling in the Danish chalk fields is due to accurate geological modelling of the reservoirs in combination with advanced geological steering techniques based on formation evaluation while drilling in the chalk reservoirs. The latter point is the subject of the present paper.

\section{Development scenarios}

Currently, geological steering techniques are used in all the major developments which rely on horizontal or highly deviated wells. This is illustrated in Table 1 and by the following four examples:

\section{Dan field (Jørgensen 1992)}

The Dan field is a domal structure of moderate relief. The reservoir chalk is mainly of Maastrichtian age, characterized by porosities in the range $20-35 \%$ and permeabilities averaging $1.75 \mathrm{mD}$. The producible oil column is up to $500 \mathrm{ft}$ thick. The Dan field is being developed with waterflooding with horizontal oil producers and horizontal water injectors completed with large diameter induced sand-propped fractures. Geological steering to optimize fracture placement is almost entirely based on on-site biostratigraphic monitoring.

\section{Tyra field (Doyle and Conlin 1987)}

The Tyra field is a very flat domal anticline with a 150-200 $\mathrm{ft}$ thick gas column overlying a thin oil rim. Porosities are very high, often above $40 \%$, and permeabilities are in the range $5-20 \mathrm{mD}$. The producible Maastrichtian oil rim varies in thickness between some 10 to $60 \mathrm{ft}$ and is being developed with long horizontal wells. 
Fig. 1. Location map of the Danish North Sea sector and the A.P. Møller concession area. Numbers indicated on the map reflect the status of completed horizontal wells as per October 1, 1993.
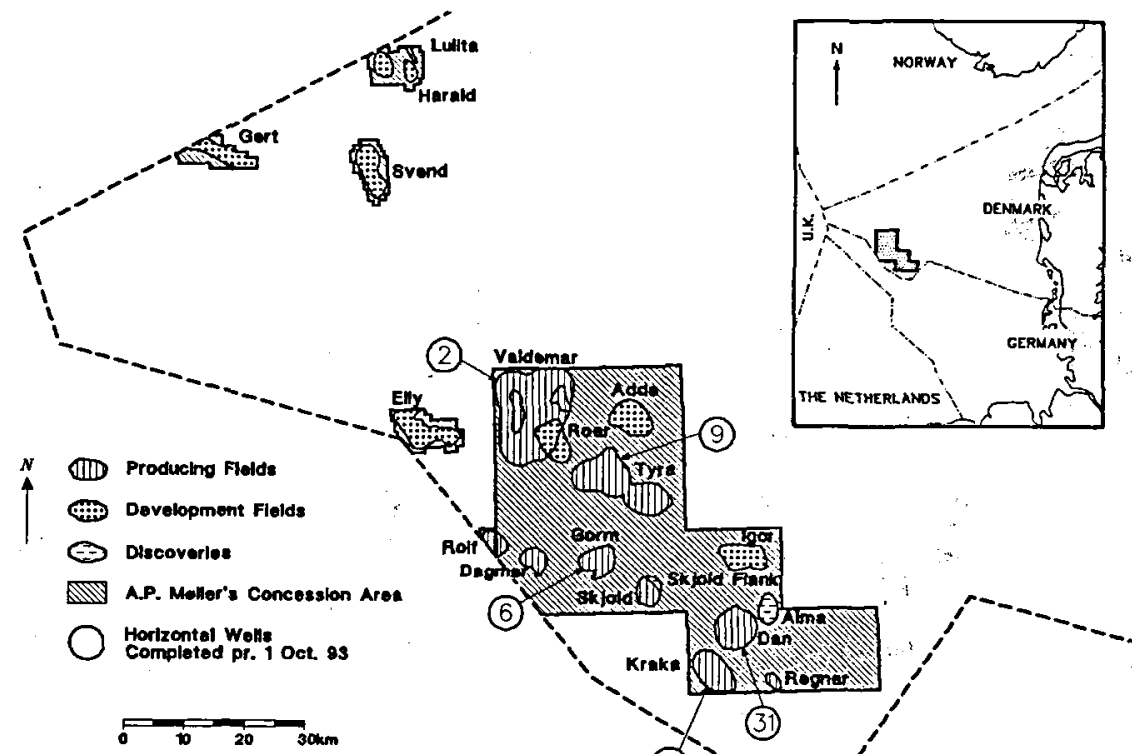

(9)

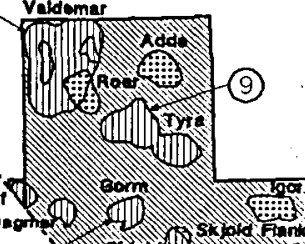

(6)

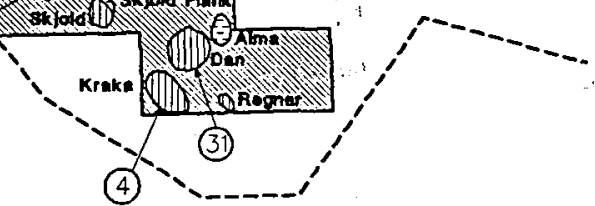

Accurate placement of the wellbore within the thin oil rim is required in order to minimize gas and water production. Geological steering is carried out to maintain given saturation or stratigraphic levels and is based on evaluation of shows, logging while drilling (LWD) techniques and on-site biostratigraphy.

\section{Skjold field (Thomasen and Larsen, in press)}

The Skjold field is a high relief salt induced structure. The reservoir chalk is highly fractured and oil production, to date, has mainly been due to imbibition of the matrix blocks within the open fracture system. An underdeveloped, less fractured, high porosity reservoir unit (35-
40\%) has been identified and is currently being developed with highly deviated oil producers and basal water injectors. Geological steering of the wells is required to maintain the wellbore in the best reservoir unit and is based on shows evaluation, LWD and on-site biostratigraphy.

\section{Kraka and Valdemar fields (Andersen and $\mathbf{J} \emptyset$ rgensen} 1991; Ineson 1991)

The Kraka field is a relatively flat domal structure with reservoir chalk of Danian age. The Valdemar structure is a broad anticline with reservoir chalk of Barremian age. Both fields are characterized by very low matrix perme-

Table 1: Applications of geological steering techniques in five Danish chalk fields.

\begin{tabular}{|c|c|c|c|}
\hline FIELD & FIELD GEOLOGY & DEVELOPMENT OBJECTIVE & $\begin{array}{l}\text { GEOLOGICAL } \\
\text { STEERING }\end{array}$ \\
\hline DAN & $\begin{array}{l}\text { Moderate relief, low permeability, medium } \\
\text { porosity, producible oil column } 350-500 \mathrm{ft} \text {, } \\
\text { Danian and Maastrichtian. }\end{array}$ & $\begin{array}{l}\text { Horizontal wells drilled in thick oil } \\
\text { column, completed with sand-propped } \\
\text { fractures. }\end{array}$ & $\begin{array}{l}\text { Biostratigraphy } \\
\text { Shows }\end{array}$ \\
\hline KRAKA & $\begin{array}{l}\text { Low relief, very low matrix permeability (avg. } \\
0.4 \mathrm{mD} \text { ), natural fractures, Danian. }\end{array}$ & $\begin{array}{l}\text { Horizontal wells drilled in thin oil } \\
\text { column near top of reservoir, } \\
\text { perpendicular to natural fractures. }\end{array}$ & $\begin{array}{l}\text { Biostratigraphy } \\
\text { Shows }\end{array}$ \\
\hline SKJOLD & $\begin{array}{l}\text { Very high relief, highly fractured on crest, less } \\
\text { fractured high porosity }(35-40 \% \text { ) unit in flank, } \\
\text { Danian-Turonian (mainly Maastrichtian). }\end{array}$ & $\begin{array}{l}\text { Highly deviated wells drilled in } \\
\text { structurally complex high porosity } \\
\text { reservoir unit. }\end{array}$ & $\begin{array}{l}\text { LWD } \\
\text { Biostratigraphy } \\
\text { Shows }\end{array}$ \\
\hline TYRA & $\begin{array}{l}\text { Very low relief, high porosity }(>40 \%) \text {, thin } \\
\text { producible oil column }(10-60 \mathrm{ft}) \text {, Danian and } \\
\text { Maastrichtian. }\end{array}$ & Horizontal wells drilled in thin oil rim. & $\begin{array}{l}\text { LWD } \\
\text { Biostratigraphy } \\
\text { Shows }\end{array}$ \\
\hline VALDEMAR & $\begin{array}{l}\text { Varying relief, very low matrix permeability } \\
\text { (avg. } 0.3 \mathrm{mD} \text { ), natural fractures, reservoir } \\
\text { section } 200 \mathrm{ft} \text {, Aptian and Barremian. }\end{array}$ & $\begin{array}{l}\text { Horizontal wells intersecting natural } \\
\text { fractures. Multiple reservoirs connected } \\
\text { with sand-propped fractures. }\end{array}$ & $\begin{array}{l}\text { Biostratigraphy } \\
\text { LWD } \\
\text { Shows }\end{array}$ \\
\hline
\end{tabular}




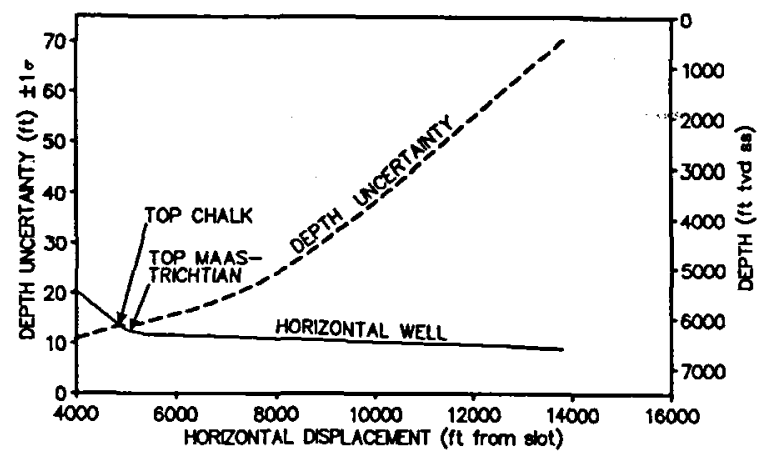

Fig. 2. Uncertainty of directional measurements along horizontal well trajectory. The example well MA-7A is the world's longest horizontal well (October 1993) completed as an oil producer in the Dan field and extended to appraise the area between the Dan and Kraka fields. In long horizontal wells the uncertainty of the depth estimate is often much larger than the thickness of the reservoir. Note that only one standard deviation is indicated.

abilities (on average $0.4 \mathrm{mD}$ and $0.3 \mathrm{mD}$, respectively) enhanced significantly by natural fracture systems.

In Kraka, where the reservoir thickness is limited, wells are being targeted close to the top of the reservoir with an azimuth perpendicular to the anticipated strike of the natural fractures. In Valdemar, which has a reservoir thickness of some $200 \mathrm{ft}$, the horizontal wells are being targeted in the centre of the reservoir interval in order to optimally place the sand-propped fractures which are created to access the complete thickness of the Barremian reservoir.

In both fields, geological steering is based on on-site biostratigraphy, LWD and shows evaluation assisted by 3D seismic data.

\section{Geological steering}

The necessity of geological steering of horizontal wells is dictated by a number of combined uncertainties associated with reservoir mapping and directional measurements. These include: The depth conversion of seismic data, the structural interpretation of the reservoir, the existence of faults and flexures below seismic resolution, and the extrapolation of reservoir fluid contacts. Inaccuracy of the downhole directional survey measurement

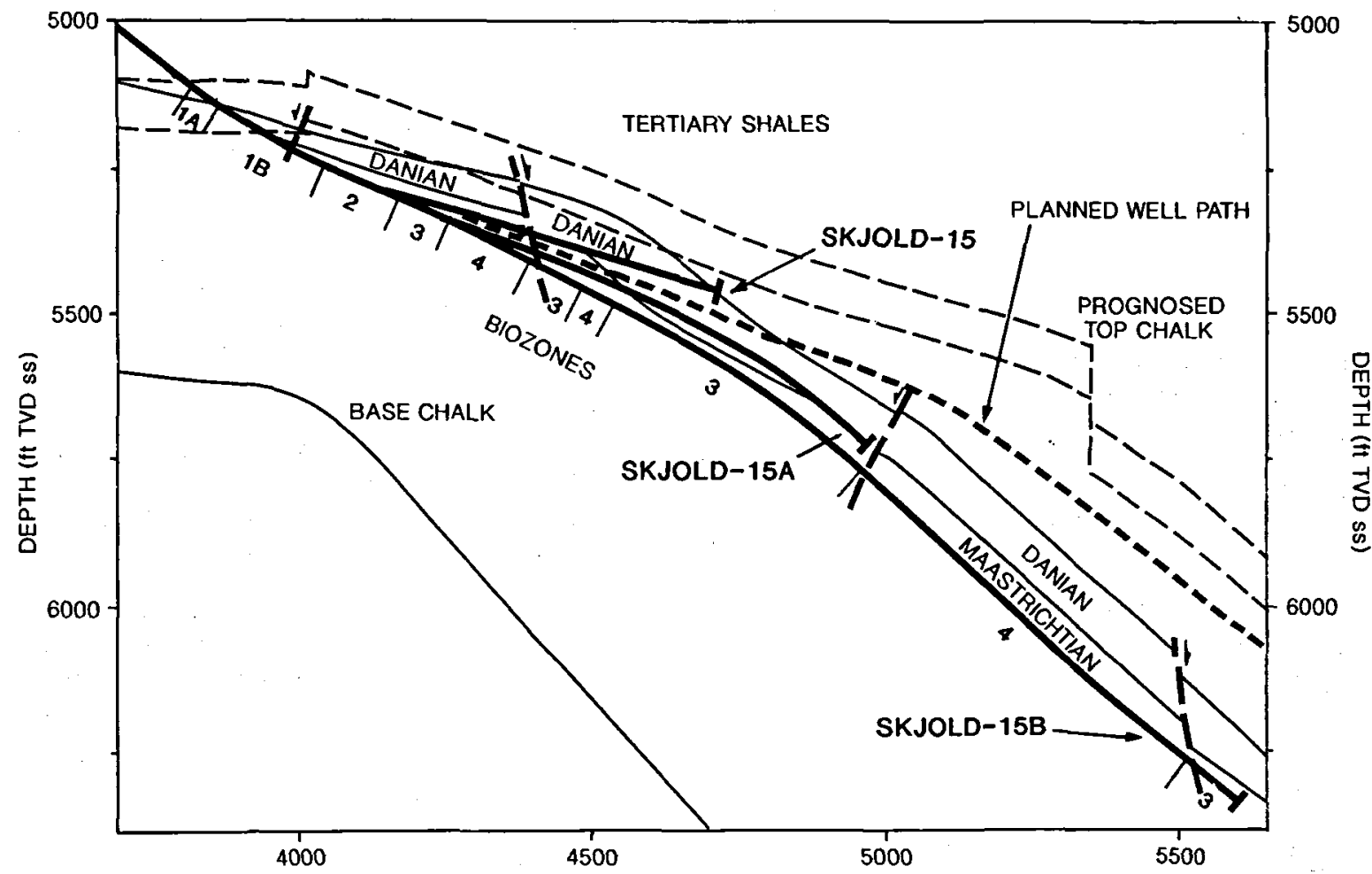

HORIZONTAL DISPLACEMENT (ft from slot)

Fig. 3. Geological cross section along the Skjold-15 well trajectory showing the encountered biostratigraphic zones. The structural interpretations made before drilling suggested a relatively uniform dip of the reservoir of some $20^{\circ}$. Top Chalk was encountered very close to the prognosed depth but the acquired biostratigraphic information demonstrated the presence of several unexpected faults and a variable dip of the structure. 
Fig. 4. Geological cross section along Dan MFB-17 showing the encountered biostratigraphic zones. The horizontal drainhole was completed with 10 sand propped hydraulic fractures and one matrix acidized interval in the uppermost porous part of the Maastrichtian reservoir characterized by the biozone DM2.

(Fig. 2) compounds the uncertainties of the reservoir models. The depth uncertainties tend to increase along the length of horizontal wells and may exceed the thickness of the target zones, especially in long horizontal wells drilled in flank areas with limited or no well control. It is consequently required to evaluate the geological data as they are acquired during drilling, in order to place the well at the optimal reservoir position and to react to unexpected geological phenomena.

\section{Well-site biostratigraphy}

Well-site biostratigraphy is very commonly used for the positioning of horizontal wells in the Danish chalk reservoirs and is applied when the objective is to maintain the horizontal wellbore at a given stratigraphic level. Detailed biostratigraphic zonation schemes have been established in the Dan, Gorm, Kraka, Skjold, and Tyra fields for the Danian and Maastrichtian, and for the Barremian chalk reservoir in the Valdemar field.

The biostratigraphic zonation schemes for each of the fields are based on local assemblage, partial-range and acme biozones of micro- and nannofossils which are established from surrounding wells and refined during drilling of the build-up sections. Which of the two fossil groups gives the best vertical resolution has been found to vary between fields and is related to the reservoir age, the depositional environment and the degree of cementation of the chalk. The thickness of individual fossil zones is generally in the order of 10-25 ft and the method provides a valuable tool for recognition of structural features of sub-seismic size.

Geological steering based on on-site biostratigraphy is reliable and inexpensive. The method does, however, suffer from being relatively slow due to the processing time involved and due to the long lag time before the drilling cuttings come to surface in long horizontal wells. An additional problem is that zone thicknesses are only measured in the build-up section of the wells and constant thickness has to be assumed along the entire length of the well. This may lead to erroneous estimates of the position of the wellbore within the reservoir and of the dip of top of the reservoir. Cyclic bio-events are another problem, which may lead to incorrect interpretations of the magnitude and direction of fault displacements. Problems caused by contamination of the drilling returns samples with cavings have, even in very long horizontal wells, been found to be negligible.

Development drilling in the Skjold field is based on geological steering by on-site analysis of nannofossils in combination with LWD measurements. The recently completed well Skjold-15 illustrates how biostratigraphic information acquired during drilling changed the structural picture as interpreted from the 3D seismic prior to drilling of the well (Fig. 3). Due to faulting and the unanticipated steep dip of the flank it was impossible to correct the trajectory while drilling the first two sidetracks. The interpretation of the structural dip was, however, changed in accordance with the biostratigraphic data and the third sidetrack was drilled successfully in the target zone to the planned TD at the oil/water contact.

The producible length of horizontal wells drilled in flank areas can be maximized with the aid of on-site biostratigraphic monitoring. Biostratigraphic monitoring allows placement of the wellbore at the highest stratigraphic position in the reservoir before the oil column wedges out towards the reservoir top. In flank areas with low structural inclination (e.g. 1-3 degrees in the Tyra field) very significant length of additional producible drainhole can be obtained by placing the wellbore stratigraphically as high as possible.

Biostratigraphic steering is used on a routine basis in the Dan field as illustrated by well MFB-17 (Fig. 4). The inner $3000 \mathrm{ft}$ of the well were drilled in varying biozones to ensure optimal positions for the 10 sand-propped fractures. Beyond this, the well was drilled in the uppermost Maastrichtian biozone with high porosity (DM2) to the $50 \%$ water saturation level. This section was separately completed and acid stimulated. By steering the trajectory with the aid of biostratigraphy it was possible to drill the well further into the flank thereby maximizing its producible length.

\section{Logging While Drilling (LWD)}

Logging While Drilling is used for geological steering of horizontal and highly deviated wells in the Valdemar, Tyra and Skjold fields where the objectives are to maintain given lithological, saturation or porosity levels within the chalk reservoirs. The method is very efficient for geological steering since it provides quantitative realtime information about important reservoir properties. 


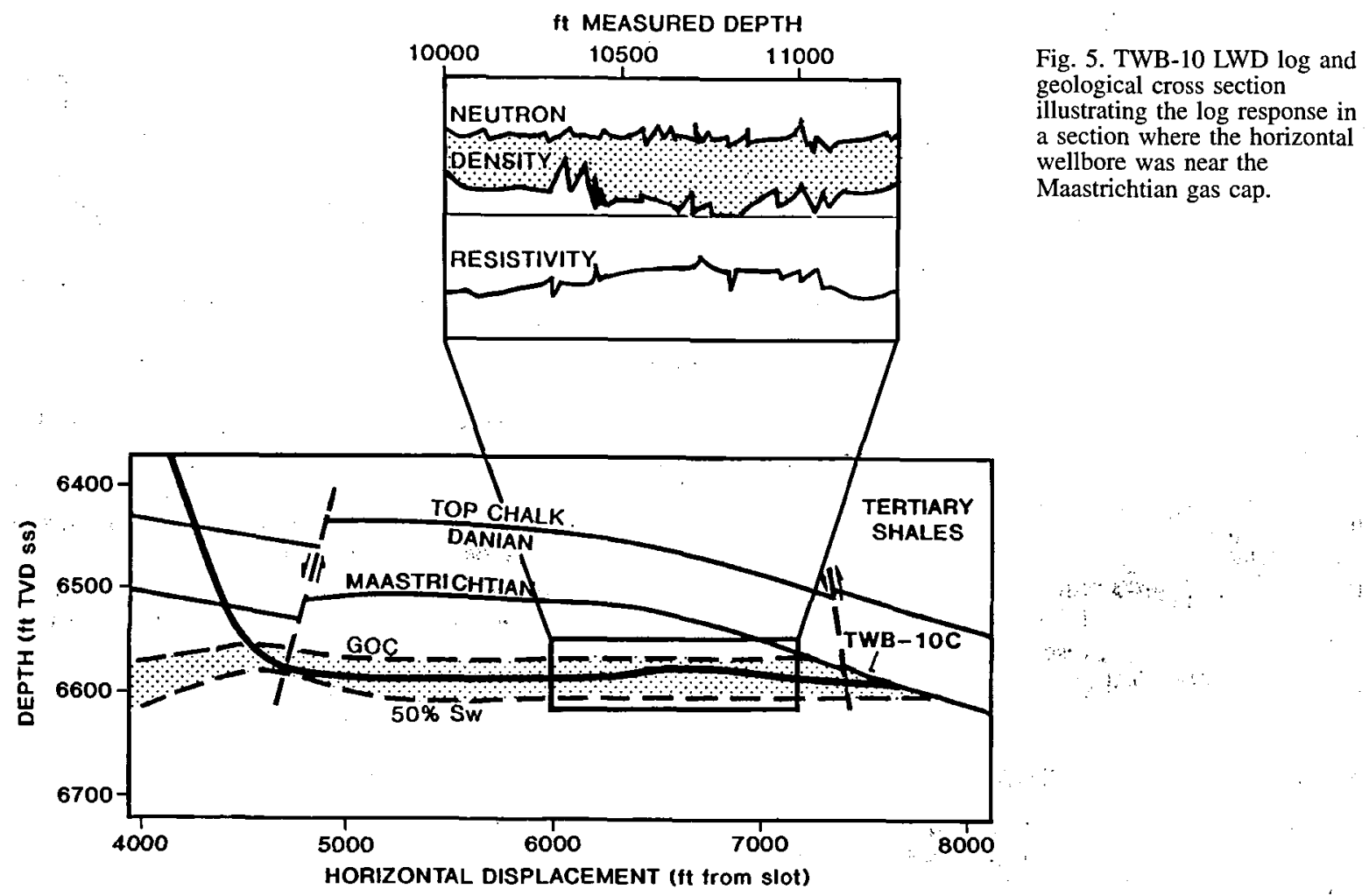

LWD measurements have a greater accuracy than other real-time formation evaluation techniques and have the advantage over wireline log data that they provide an estimate of true formation saturation before any significant mud filtrate invasion has occurred.

The main disadvantage in using LWD is its high cost. An additional problem is that the LWD tools usually are located some $50-80 \mathrm{ft}$ behind the bit which causes a delay in the data acquisition. This delay may be critical in wells where the target is narrowly defined. Finally, it has been found, that some LWD tools, which are constructed with full gauge stabilizers for the density sensors, may interfere with the orienting ability of the bottom hole assembly and make it more difficult to correctly position the well.

LWD is used on a standard basis for the current development drilling of horizontal wells in the Tyra field when drilling in the Maastrichtian oil rim below the gas cap. LWD is used to position the wells in the centre of the thin oil rim which is essential to minimize water and gas production from the wells. A section of an LWD $\log$ from Tyra well TWB-10C, drilled in 1992, illustrates how this is achieved (Fig. 5). The log section suggests a close correlation between the vertical depth of the wellbore and the corresponding resistivity level, which is commonly observed in the chalk fields. From 10,250 ft measured depth the inclination of the wellbore and the LWD resistivity both increase to a maximum at $10,700 \mathrm{ft}$ which indicate that the well was drilled upwards in the oil rim. Over the same interval an increasing separation between the neutron and the density logs was observed indicating that the wellbore as it was drilled upwards was coming close to the overlying gas zone. As soon as the LWD data were acquired the well trajectory was turned down in order not to re-enter the gas cap and the remaining part of the well was successfully placed in the oil rim.

This example demonstrates how LWD is used in the Tyra field for targeting a saturation level and shows that the information from LWD can be used in a predictive manner so that corrective action can be taken before the wellbore deviates outside the reservoir target zone.

\section{Evaluation of hydrocarbon shows}

Subtle properties of the hydrocarbons trapped in cuttings, such as fluorescence and colour of the hydrocarbon after treatment with organic solvent, have been found to correlate with the saturation level measured by petrophysical logs. This relationship has made evaluation of hydrocarbon shows a general and very useful tool for the geological steering of horizontal wells when the objective is to maintain a given saturation level. In the early horizontal wells the method was used on its own, but it is now more commonly used in conjunction with other evaluation 
methods or as a fall back option in case of failure of the LWD.

Hydrocarbon shows evaluation is very labour intensive but significantly less costly than LWD. It requires continuous monitoring of the shows and has the disadvantage of being far behind the position of the bit when drilling is fast $(200-400 \mathrm{ft} / \mathrm{hr})$ as it often is the case in soft chalk reservoirs. Estimation of the saturation level from shows can be accurate in well known fields but requires a large amount of experience by the on-site geologist. Due to variations in porosity, permeability, fluid composition etc. between reservoirs, an equivalent oil saturation may give poor oil shows in one field and very good oil shows in another. An additional problem in steering by hydrocarbon shows may be that the geologist's interpretation is somewhat subjective and may drift during the drilling phase especially if the reservoir section is extensive.

\section{D seismic}

3D seismic data sets are available for all the Danish chalk fields under development. The high resolution seismic data are not only of significant value in the planning of overall field development strategies but are also used on a routine basis for the design of horizontal wells. During the drilling of a well the interpreted seismic profile along the planned well trace is available on a work station in the office and a large scale paper copy is available at the rig-site.

If an unexpected structural feature, affecting the well trajectory is encountered, the seismic interpretation can be updated immediately. The revised seismic interpretation makes it possible to interprete the structural configuration ahead of the actual position of the bit take remedial action if required. However, during drilling in very thin reservoirs the horizontal well trajectory may be critically affected by faults and flexures below the vertical resolution of the 3D seismic data.

The steering of well Kraka A-7 was significantly improved by analysis of the 3D seismic during drilling. Before the well was drilled a seismic interpretation was made suggesting that the Top Chalk structure was a rather uniform surface dipping some 2 degrees in the direction of the well. During drilling in the uppermost Danian chalk an unexpected fault with a vertical displacement of less than $20 \mathrm{ft}$ was encountered and the wellbore entered the Tertiary shale above the reservoir. The seismic interpretation was then revised and several subtle features, similar to the first small fault, were recognized. The well was pulled back and sidetracked, and corrections were made to the trajectory in order to compensate for the newly recognized faults. This re-interpretation process made it possible to place the entire $7500 \mathrm{ft}$ of drainhole within the uppermost $40 \mathrm{ft}$ of the chalk reservoir.

\section{Pilot holes}

Pilot holes were drilled in Marsk's early horizontal wells to provide a complete profile through the reservoir and precisely define stratigraphic levels and fluid contacts above and below the target level of the later horizontal sidetrack. A major disadvantage was the high cost of drilling, logging and plug-back of the pilot holes which are currently omitted in most fields. The information gained in a pilot hole was also found to be of limited value when the reservoir is structurally complex since it only provided control in the beginning of the horizontal sidetrack close to the site of the pilot hole. In very thin reservoirs it was found that inaccuracies in the directional surveys and lateral variations within the reservoir, between the two holes, exceeded the thickness of the reservoir target zone thereby eliminating the value of the pilot hole data.

With faster and more accurate geological evaluation techniques it has become possible to overcome these problems and adjust the well trajectory to the horizontal target during drilling. Pilot holes are therefore, at present, only drilled for appraisal purposes in fields with limited well control.

\section{Conclusion}

The examples given illustrate the current applications of geological steering techniques for placement of horizontal wellbores in complex reservoir target zones in the Danish chalk fields. Geological steering in these reservoirs is required to accommodate depth uncertainties of the current reservoir models and survey inaccuracies.

Geological steering has led to considerable cost savings by eliminating the need for pilot holes to target horizontal wells. With accurate geological steering, horizontal wells in the Danish chalk reservoirs are optimized both in terms of maximizing the productive length of the drainhole and placing the well correctly within the narrow target to accomplish the chosen completion objectives.

\section{Acknowledgements}

The author wishes to thank the management of Mærsk Olie og Gas AS, Texaco Denmark Inc. and Shell Olie og Gasudvinding Danmark BV (Holland) for permission to publish this paper. My colleagues at Marsk Olie og Gas AS and Michael R. Yusas (Texaco) are thanked for sharing their experience in horizontal drilling with me and for discussions and reviews which greatly improved the quality of the present paper. 


\section{Dansk Sammendrag}

Mere end 50 horisontale boringer er, siden 1987, blevet udført i den danske Nordsø-sektor. Den horisontale boreteknik har vist sig at være særdeles velegnet til udvikling af lav-permeable kalk reservoirer. Horisontale og stærkt devierede brønde er således basis for de igangværende udbygninger af olie- og gasfelterne: Dan, Kraka, Gorm, Skjold, Tyra og Valdemar. Geologisk styring af de horisontale brønde er nødvendig for at imødegå de ofte store dybdeusikkerheder af reservoir positionen. Styringen baseres på tolkning af geologiske data opsamlet under boringen. De hyppigst anvendte geologiske analysemetoder omfatter: Biostratigrafisk analyse, Logging While Drilling (LWD), detaljeret analyse af hydrokarboner indeholdt $\mathrm{i}$ borespåner, samt analyse af 3D seismiske data. Biostratigrafisk analyse anvendes når boringer skal følge givne stratigrafiske niveauer. Biostratigrafiske zone tykkelser på under 8 meter er etableret i reservoir sektionerne i de fleste kalkfelter. Logging While Drilling anvendes når boringer skal følge givne porøsitets-, eller oliemætnings- intervaller og omfatter logdata transmitteret til overfladen under boringen. Den visuelle karakter af olie i borespåner korrellerer godt med målte oliemætninger og vurderes detaljeret under alle boringer. Denne simple metode anvendes når boringer skal følge givne oliemætningsniveauer og som erstatning for de relativt dyre LWD målinger. 3D seismiske data er tilgængelige for alle de større kalkfelter og analyseres detaljeret såvel før som under boringen af alle typer brønde. Baseret på reviderede seismiske tolkninger kan brøndpositionerne, hvis det er påkrævet, ændres undervejs. Pilothuller var tidligere anvendt til at fastlægge reservoirpositionen for horisontale boringer. Geologisk styring ved hjælp af de beskrevne teknikker har imidlertid ført til udeladelse af pilothullerne, idet det er blevet muligt at justere brøndpositionerne under boringen. Den omfattende geologiske analyse har endvidere muliggjort en mere præcis placering af de horisontale borehuller i kalkreservoireme, hvilket er af vital betydning for brøndenes produktivitet.

\section{References}

Andersen, S. A., Conlin, J. M., Fjeldgaard, K. \& Hansen, S. A. 1990: Exploiting Reservoirs with Horizontal Wells: The Mærsk Experience. Schlumberger Oilfield Review 2, 11-21.

Andersen, P. M. \& Jørgensen, L. N. 1991: Integrated Study of the Kraka Field, Paper SPE 23082, presented at the Offshore Europe Conference, Aberdeen, 3-6 September 1991, 461474.

Doyle, M. C. \& Conlin, J. M. 1987: The Tyra Field. North Sea Oil and Gas Reservoirs II, The Norwegian Institute of Technology (Graham and Trotman), 47-65.

Fine, S., Yusas, M.R. \& Jørgensen, L.N. 1992: Geological Aspects of Horizontal Drilling in Chalks from the Danish Sector of the North Sea. In J. Parker (Ed.): Petroleum Geology of Northwest Europe: Proceedings of the 4th Conference. London, 1483-1490.

Ineson, J. R. 1991: The Lower Cretaceous Chalk Play in the Danish Central Trough. In J. Parker (Ed.): Petroleum Geology of Northwest Europe: Proceedings of the 4th Conference. London, 175-183.

Jørgensen, L. N. 1992: The Dan Field. AAPG Treatise of Petroleum Geology. Atlas of Oil and Gas Fields, 199-218.

Thomasen, J.B. \& Larsen, F. P. (in press). A Multidisciplinary Study for Development Optimization in a Fractured Chalk Field. To be presented at the World Petroleum Congress, Stavanger, 1994. 